\title{
PENERAPAN MODEL CONTEXTUAL TEACHING ANG LEARNING MELALUI PEMANFAATAN LINGKUNGAN SEKITAR UNTUK MENINGKATKAN HASIL BELAJAR IPA KELAS V SD 1 PEGANJARAN KUDUS
}

\author{
Khakim, Sri Utaminingsih, Fina Fakhriyah \\ Pendidikan Guru sekolah Dasar, FKIP Universitas Muria Kudus \\ lutfilhakim31@yahoo.co.id
}

\begin{abstract}
The purpose of this study is to describe and analyze student learning outcomes with the application of Contextual Teaching And Learning by exploiting the environment to improve student learning outcomes in the material properties of light science subjects in class V SD 1 Peganjaran Kudus.

In the cycle I, the percentage of teacher's capability is $76,87 \%$ with good criteria and increased to $84,37 \%$ with good criteria in cycle II. The percentage of student learning achievement on affective domain in cycle I is $56,67 \%$ with sufficient criteria and increased to $87,21 \%$ with good criteria in cycle II. The percentage of student learning achievement on psychomotor domain in cycle $\mathrm{I}$ is $56,57 \%$ with sufficient criteria and increased to $83,41 \%$ with good criteria in oycle II.

Based from these indicator it can be concluded that implementation of contextual teaching and learning model through environment can improve Science learning achievement in $5^{\text {th }}$ students of SD 1 Peganjaran Kudus. Based from this conclusion, the researcher need to ask advice for the teacher to develop contextual teaching and learning through environment to make the students more easier to understand the subject material.
\end{abstract}

Keyword: Science Learning Achievement, Contextual Teaching and Learning Model, Environment, Properties of Light.

\section{RINGKASAN}

Tujuan penelitian ini untuk mendiskripsikan dan menganalisis hasil belajar siswa dengan penerapan model Contextual Teaching And Learning dengan memanfaatkan lingkungan sekitar untuk meningkatkan hasil belajar siswa pada materi sifat-sifat cahaya mata pelajaran IPA kelas V SD 1 Peganjaran Kudus.

Hasil penelitian siklus I keterampilan guru mencapai persentase ketuntasan 76.87\% "baik" dan mengalami peningkatan siklus II menjadi $84.37 \%$ dengan kriteria "baik". Hasil belajar IPA siswa ranah kognitif pada siklus I 52.63\% dan pada siklus II meningkat menjadi $84.21 \%$. Hasil belajar IPA ranah afektif siswa siklus I mencapai persentase $56.67 \%$ dengan kriteria "cukup" dan siklus II meningkat menjadi $87.23 \%$ dengan kriteria "baik" dan ranah psikomotorik siswa siklus I mencapai persentase $56.57 \%$ dengan kriteria "cukup" dan siklus II meningkat menjadi $83.41 \%$ dengan kriteria "baik". 
Simpulan pada penelitian ini yakni dengan menggunakan model CTL melalui lingkungan sekitar dapat meningkatkan hasil belajar IPA siswa kelas $\mathrm{V}$ SD 1 Peganjaran Kudus. Peneliti menyarankan agar penggunaan model CTL dapat diterapkan oleh setiap pengajar dan dikembangkan melalui pemanfaatan lingkungan sekitar sehingga siswa bisa mudah dalam menyerap pelajaran.

Kata Kunci: Hasil Belajar IPA, Model Contextual Teaching and Learning, Pemanfaatan Lingkungan Sekitar, Sifat-sifat Cahaya.

\section{PENDAHULUAN}

Pendidikan nasional berfungsi mengembangkan kemampuan dan membentuk watak serta peradaban bangsa yang bermartabat dalam rangka mencerdaskan kehidupan bangsa, bertujuan untuk berkembangnya potensi peserta didik agar menjadi manusia yang beriman dan bertakwa kepada Tuhan Yang Maha Esa, berakhlak mulia, sehat, berilmu, cakap, kreatif, mandiri, dan menjadi warga negara yang demokratis serta bertanggung jawab. Upaya untuk menghantarkan anak didik ke jenjang yang lebih sempurna khususnya melalui jalur formal yaitu di sekolah dasar senantiasa mengadakan peningkatan dan penyempurnaan mutu pendidikan untuk dapat mencapai tujuan pendidikan secara optimal, - salah satunya melalui peningkatan kualitas kegiatan pembelajaran. Tujuan pembelajaran tersebut untuk membantu siswa agar memperoleh berbagai pengalaman dan dengan pengalaman itu tingkah laku yang dimaksud meliputi pengetahuan, keterampilan, dan nilai atau norma yang berfungsi sebagai pengendali sikap dan perilaku siswa.
Penelitian ini dilaksanakan di SD 1 Peganjaran yang sebagian besar siswa kelas $\mathrm{V}$ tidak tuntas hasil belajarnya dengan kriteria ketuntasan minimal (KKM) adalah 65. Terlihat dari data 20 siswa, sebanyak 11 siswa $\quad(55 \%) \quad$ mengalami ketidaktuntasan dalam mencapai KKM, sedangkan 9 siswa $(45 \%)$ mengalami ketuntasan mencapai KKM. Dengan melihat data hasil belajar tersebut, maka perlu ditingkatkan hasil belajar pada siswa, sebagai upaya peningkatan kualitas pembelajaran. Upaya untuk memecahkan masalah tersebut maka peneliti menerapkan salah satu alternatif yang akan dilakukan yaitu dengan menerapkản model Contextual Teaching and Learning (CTL) dengan memanfaatkan lingkungan sebagai sumber belajar yang nantinya akan disesuaikan dengan materi pembelajaran.

Tujuan penelitian ini untuk mendiskripsikan dan menganalisis hasil belajar siswa dengan penerapan model Contextual Teaching And Learning dengan memanfaatkan lingkungan sekitar untuk meningkatkan hasil belajar siswa pada materi sifat-sifat cahaya mata 
$\begin{array}{llllll}\text { pelajaran } & \text { IPA } & \text { kelas } & \text { V } & \text { SD } & 1\end{array}$

Peganjaran Kudus.

\section{KAJIAN PUSTAKA DAN HIPOTESIS TINDAKAN}

\section{Model Pembelajaran \\ Contextual Teaching and \\ Learning}

Daryanto dan Raharjo, (2012:

155) pembelajaran kontekstual

(Contextual Teaching and learning) adalah konsep belajar yang membantu guru mengaitkan antara materi yang diajarkannya dengan situasi dunia nyata siswa dan mendorong siswa membuat hubuangan antara pengetahuan yang dimilikinya dengan penerapannya dalam kehidupan mereka sehari-hari, dengan melibatkan tujuh komponen utama pembelajaran efektif, yakni: kontruktivisme (Contructivism), bertanya (Questioning), menemukan (Inquiri), masyarakat belajar (Learning Community), pemodelan (Modeling), dan penilaian sebenarnya (Authentic Assesment).

Sedangkan Sanjaya (2007:

253) Contextual Teaching and

Learning (CTL) adalah suatu strategi pembelajaran yang menekankan kepada proses keterlibatan siswa secara penuh untuk dapat menemukan materi yang dipelajari dan menghubungkan dengan situasi kehidupan nyata sehingga mendorong siswa untuk dapat menerapkannya dalam kehidupan mereka.
Dari pengertian model pembelajaran Contextual Teaching and Learning diatas, maka dapat disimpulkan bahwa pembelajaran Contextual Teaching and Learning suatu pola yang membantu guru di dalam pembelajaran untuk mengaitkan konten pelajaran dengan dunia nyata siswa sehingga siswa bisa menerapkan pengetahuannya dalam kehidupan sehari-hari.

\section{Lingkungan Belajar}

Andrianto (2011: 7) Lingkungan sebagai sumber belajar dapat diartikan sebagai kesatuan ruang dengan semua benda dan keadaan makhluk hidup, (termasuk di dalamnya manusia dan perilakunya serta makhluk hidup lainnya), sehingga memungkinkan anak usia dini untuk belajar tentang informasi, orang, bahan dan alat.

Saroni (2013: 110), mendefinisikan lingkungan belajar adalah segala sesuạtu yang berhubungan dengan tempat proses pembelajaran dilaksanakan. Lingkungan ini mençangkup dua hal utama, yaitu lingkungan fisik dan lingkungan sosial. Lingkungan fisik adalah lingkungan yang ada di sekitar siswa belajar, berupa sarana fisik, baik yang ada di dalam sekolah maupun di sekitar sekolah, termasuk masyarakat seperti ruang kelas, alat/media belajar. Sedangkan lingkungan sosial berhubungan dengan pola interaksi antar personil yang memungkinkan para siswa untuk berinteraksi secara baik, mulai 
dari siswa dengan siswa, guru dengan siswa, siswa dengan karyawan, serta siswa dengan masyarakat umum.

Semua jenis lingkungan yang ada di sekitar anak pada dasarnya dapat dimanfaatkan untuk mengoptimalkan kegiatan pembelajaran anak.

Menurut Andrianto, (2011: 9) menjelaskan jenis lingkungan yang dapat dimanfaatkan dalam kegiatan pembelajaran di Sekolah Dasar dapat berupa lingkungan alam, lingkungan sosial, dan lingkungan budaya. Uraian tentang lingkungan alam, lingkungan sosial, dan lingkungan budaya adalah sebagai berikut:

1) Lingkungan alam atau lingkungan fisik adalah segala sesuatu yang sifatnya alamiah, seperti sumber daya alam (air, hutan, batu-batuan), tumbuhtumbuhan dan hewan, sungai, suhu, dan sebagainya.

Lingkungan alam sifatnya relatif tetap, oleh karena itu jenis lingkungan ini akan lebih mudah dikenali oleh anak. Dengan mempelajari lingkungan alam ini, diharapkan anak akan lebih memahami gejala-gejala alam yang terjadi dalam kehidupannya, dan juga dapat menumbuhkan kesadaran untuk mencintai alam dan turut berpartisipasi untuk menjaga dan memelihara lingkungan alam

2) Lingkungan sosial kaya akan informasi bagi anak-anak. Hal- hal yang bisa dipelajari oleh anak dengan pemanfaatan lingkungan sosial sebagai sumber belajar, misalnya:

a. Mengenal jenis-jenis mata pencaharian penduduk di sekitar tempat tinggal dan sekolah.

b. Mengenal adat istiadat dan kebiasaan penduduk setempat di mana anak tinggal.

c. Mengenal organisasiorganisasi sosial yang ada di masyarakat sekitar tempat tinggal dan sekolah.

d. Mengenal kehidupan beragama yang dianut oleh penduduk sekitar tempat tinggal dan sekolah.

e. Mengenal kebudayaan termasuk kesenian yang ada di sekitar tempat tinggal dan sekolah.

f. Mengenal susunan pemerintahan setempat seperti RT, RW, desa atau kelurahan dan kecamatan.

3) Lingkungan budaya yaitu lingkungan yang sengaja diciptakan atau dibangun manusia untuk tujuan-tujuan tertentu yang bermanfaat bagi kehidupan manusia.

Jenis lingkungan yang telah dikemukakan di atas, dapat dimanfaatkan dalam proses pembelajaran di sekolah. Dengan begitu lingkungan dapat berfungsi untuk memperkaya bahan ajar, 
memperjelas konsep dan prinsip yang dipelajari serta dapat menumbuhkan kesadaran, cinta alam dan siswa turut berpartisipasi dalam menjaga dan memelihara lingkungan.

Dari pengertian-pengertian diatas, maka dapat disimpulkan lingkungan sekitar merupakan segala sesuatu yang ada di sekitar siswa yang bisa digunakan oleh siswa di dalam pembelajaran yang bertujuan untuk membantu dalam proses pembelajaran agar materi yang diajarkan mudah dipahami oleh siswa. Lingkungan sekitar yang digunakan yaitu (1) gudang gelap ada di sekolah yang termasuk jenis lingkungan fisik, (2) cahaya matahari yang termasuk lingkungan alam, (3) barang bekas berupa kardus bekas digunakan untuk membuat produk periskup yang termasuk lingkungan budaya, dan (4) barang bekas berupa lampu digunakan untuk membuat lup yang termasuk jenis lingkungan budaya.

\section{Hasil Belajar IPA}

Hasil belajar menurut Bloom (dalam Suprijono, 2013: 67)mencakup 3 kemampuan, yaitu: (1) domain kognitif adalah knowledge (pengetahuan, ingatan), comprehension (pemahaman, menjelaskan, meringkas, contoh), application (menerapkan), analysis (menguraikan, menentukan hubungan), synthesis (mengorganisasikan, merencanakan, membentuk bangunan baru), dan evaluation (menilai), (2) domain afektif adalah receiving (sikap menerima), responding (memberikan respon), valuing (nilai), organization (organisasi), characterization (karakterisasi), (3) domain psikomotor adalah keterampilan produktif, teknik, fisik, sosial, manajerial dan intelektual.

Menurut Aly dan Eny (2000: 18) IPA adalah suatu pengetahuan teoritis yang diperoleh/disusun dengan cara yang khas/khusus, yaitu melakukan observasi eksperimentasi, penyimpulan, penyusunan teori, eksperimentasi, observasi dan sedemikian seterusnya kaitmengakait antara cara yang satu dengan cara yang lain. Adapun tujuan pembelajaran IPA menurut menurut Trianto (2010: 142) yaitu: (1)memberika pengetahuan kepada siswa tentang dunia tempat hidup dan bagaimana bersikap, (2)menanamkan sikap hidup ilmiah, (3) memberikan keterampilan untuk melakukan pengamatan, (4)mendidik siswa untuk menangani, mengetahui cara kerja serta menghargai para ilmuan penemunya, (5)menggunakan dan menerapkan metode ilmiah dalam memecahkan permasalahan.

\section{Sifat-Sifat Cahaya}

Menurut Hanifah (2012: 59-

63) cahaya adalah suatu bentuk energi. Cahaya bergerak merambat di udara dalam garis lurus. Gerak energi cahaya di angkasa dapat mencapai kecepatan $299.792 \mathrm{~km}$ per detik. Energi cahaya berbentuk 
radiasi electromagnet yang terpancar dari suatu reaksi fisika, baik yang berasal dari reaksi pada listrik maupun reaksi pada inti atom suatu medan energi seperti halnya yang terjadi pada matahari.

Cahaya merupakan bagian dari fenomena fisika. Seluk beluk cahaya sebagai suatu bentu energi telah menjadi bahan perdebatan sejak dahulu. Dari fenomena fisika ini, banyak ilmuwan yang mengemukakan berbagai gagasan tentang cahaya. Akan tetapi, di dalam ilmu pengetahuan, kebenaran dari suatu gagasan maupun teori akan sangat ditentukan oleh uji eksperimen.

Menurut Imuwan Abu Ali Hasab Ibn Al-Haitham dalam Hanifah (2012: 60) menyatakan bahwa setiap titik pada daerah yang tersinari cahaya, mengeluarkan sinar cahaya ke segala arah, tetapi hanya satu sinar dari setiap titik yang masuk ke mata secara tegak lurus yang dapat dilihat, sedangkan cahaya lain yang mengenai mata tidak secara tegak lurus tidak dapat dilihat.

\section{Kerangka Berpikir}

Kegiatan

pembelajaran, hambatan yang biasa muncul adalah hasil belajar siswa yang rendah. Begitu pula pada kegiatan pembelajaran pada mata pelajaran IPA tidak hanya teori saja, melainkan ada praktiknya. Sehingga di dalam pembelajaran tidak diselingi dengan praktik, yaitu memanfaatkan lingkungan disekitar sekolah, maka siswa pun merasa bosan dan tidak termotivasi dalam mengikuti pembelajaran. Berdasarkan hal tersebut, seharusnya pembelajaran IPA dijadikan dalam suatu pembelajaran yang menyenangkan, bermakna, dan dapat memotivasi siswa untuk bersemangat mengikuti proses pembelajaran.

Upaya untuk mengatasi permasalahan tersebut salah satunya dengan menerapkan model Contextual Teaching and Learning dengan memanfatkan lingkungan sekitar sebagai sumber belajar yang nyata dan menarik dapat menumbuhkan motivasi serta mengembangkan pola berpikir kritis sehingga dapat meningkatkan hasil belajar pada pelajaran IPA. Melalui penerapan model Contextual Teaching and Learning dengan memanfaatkan lingkungan sekitar sebagai sumber belajar siswa berpartisipasi aktif dalam seluruh proses pembelajaran IPA. Dengan demikian, proses pembelajaran akan menjadi menyenangkan dan hasil belajar siswa akan meningkat.

\section{Hipotesis Tindakan}

Hipotesis tindakan penelitian ini yaitu melalui penerapan model Contextual Teaching and Learning dengan memanfaatkan lingkungan sekitar, dapat meningkatkan hasil belajar siswa pada materi sifat-sifat cahaya mata pelajaran IPA kelas $\mathrm{V}$ SD 1 Peganjaran Kudus.

\section{METODE PENELITIAN}


Subjek dalam Penelitian ini adalah siswa kelas V SDN I Peganjaran Kecamatan Bae Kabupaten Kudus, pada tahun 2013/2014 yang berjumlah 20 siswa. Terdiri dari 13 siswa laki-laki dan 7 siswa perempuan. Keadaan siswa kelas V SDN Peganjaran Kudus memiliki keberagaman seperti perbedaan latar belakang ekonomi, kemampuan berfikir, perkembangan psikologis maupun bakat dan minat yang berbeda antar satu dengan yang lainnya. Penelitian ini ada dua variabel yaitu (1) variabel bebas yakni model CTL, (2) variabel terikat yakni hasil belajar IPA kelas V SD 1 Peganjaran.

$$
\text { Suwandi (2011: }
$$

menyatakan bahwa PTK bertujuan tidak hanya mengungkapkan penyebab dari berbagai kesulitan siswa dalam memahami pokokpokok bahasan tertentu, tetapi yang lebih penting lagi adalah memberikan solusi berupa tindakan untuk mengatasi permasalahan pembelajaran tersebut.

Pelaksanaan PTK terdapat

empat tahapan penting yaitu: (1) perencanaan; (2) pelaksanaan; (3) pengamatan; (4) refleksi. Keempat tahap dalam penelitian tindakan tersebut adalah unsur untuk membentuk sebuah siklus, yaitu satu putaran kegiatan beruntun, yang kembali ke langkah semula.

\section{Teknik Pengumpulan Data}

Teknik pengumpulan data yang dilakukan pada penelitian ini adalah metode observasi, metode tes, dan dokumentasi. Berikut ini penjelasan mengenai teknik-teknik yang digunakan peneliti dalam pengumpulan data menurut Arikunto (2010: 266-275).

a. Metode observasi

Penelitian ini yang digunakan peneliti adalah observasi partisipasif yang digunakan untuk mengamati aktivitas siswa dalam pembelajaran IPA melalui pemanfaatan lingkungan sebagai sumber belajar serta pengamatan terhadap guru yang sedang mengajar.

\section{b. Metode tes}

Tes yang dimaksud dalam penelitian disini yaitu postest yang dilakukan sebagai evaluasi terhadap model contextual teaching and learning yang digunakan| dalam penelitian tersebut. Bentuk tes yang digunakan yaitu pilihan ganda, dengan jumlah soal pada tes siklus 1 dan 2 sebanyak 45 butir soal, dengan tingkat ranah kognitif C1-C6.

c. Dokumentasi

Dokumen yang digunakan dalam penelitian ini berupa catatan lapangan, foto kegiatan pembelajaran, serta dokumen lain yang mendukung. Tujuan dokumentasi dalam penelitian ini adalah untuk memberikan gambaran secara konkret aktivitas belajar siswa, keterampilan guru dalam mengajar, serta suasana kelas ketika pembelajaran sedang berlangsung.

\section{Teknik Analisis Data}


Teknik analisis data dapat dijelaskan mengenai hasil belajar siswa, jika presentase yang diperoleh $<20 \%$ maka mendapat kriteria sangat Rendah, jika presentase20-39\% maka mendapat kriteria rendah, jika presentase40-59\% maka mendapat kriteria sedang, jika presentase 6079\% maka mendapat kriteria tinggi, dan jika presentase $>80 \%$ maka mendapat kreteria sangat tinggi. Adapun penjelasan mengenai aktivitas belajar siswa yang diperoleh antara $0-54 \%$ maka mendapat kriteria kurang, jika presentase $55-64 \%$ maka mendapat kriteria cukup, jika presentase 65$84 \%$ maka mendapat kriteria baik, dan jika presentase $85-100 \%$ maka mendapat kriteria sangat baik. Sedangkan untuk menganalisis hasil keterampilan guru, jika presentase yang diperoleh antara 0-54\% maka mendapat kriteria kurang, jika presentase $55-64 \%$ maka mendapat kriteria cukup, jika presentase 65$84 \%$ maka mendapat kriteria baik, dan jika presentase $85-100 \%$ maka mendapat kriteria sangat baik.

\section{HASIL DAN PEMBAHASAN}

Hasil belajar merupakan perolehan dari proses tindak belajar siswa yang menunjukkan suatu perubahan tingkah laku atau perolehan kognitif, afektif, dan psikomotorik. Hasil penelitian yang didapat dari pelaksanaan siklus I dan siklus II dapat dinyatakan bahwa pembelajaran IPA melalui penerapan model CTL melalui pemanfaatan lingkungan sekitar dapat meningkatkan hasil belajar IPA kelas V SD 1 Peganjaran, baik kemampuan aspek kognitif, afektif dan psikomotorik. Peneliti menggunakan tes akhir siklus sebagai alat untuk mengukur peningkatan hasil belajar siswa pada aspek kognitif. Lembar aktivitas belajar siswa yang digunakan untuk mengetahui letak peningkatan hasil belajar siswa aspek afektif dan psikomotorik. Sedangkan lembar pengamatan guru dalam pengelolaan pembelajaran digunakan untuk mengetahui letak peningkatan kualitas pembelajaran yang telah dilakukan melalui penerapan model CTL melalui pemanfaatan lingkungan sekitar pada mata pelajaran IPA.

Pelaksanaan pembelajaran menggunakan model pembelajaran CTL melalui pemanfaatan lingkungan sekitar pada siklus I, maka diperoleh nilai rata-rata kelas dari 19 siswa yaitu 60,63 dengan persentase ketuntasan klasikal $52.63 \%$ atau sebanyak 10 siswa tuntas dan masih ada 9 siswa yang belum mencapai KKM. Maka guru melanjutkan siklus ke II untuk materi membuat alat peraga sederhana dengan menindak lanjuti siklus I. Hasil refleksi siklus I yang dilakukan diperoleh kesimpulan bahwa pelaksanaan penelitian tindakan kelas pada siklus I belum mencapai 
ketuntasan belajar klasikal yang telah ditetapkan yaitu $75 \%$.

1) Pengamatan Aktivitas Belajar Siswa

Hasil pengamatan aktivitas belajar siswa siklus 1 pada aspek afektif didapatkan rata-rata dalam persentase sebesar $56.97 \%$ dengan kriteria aktivitas belajar siswa dalam kategori cukup, sehingga harus diingkatkan lagi untuk menjadikan pembelajaran yang ideal dan mendapatkan klasifikasi baik. Hal yang harus dibenahi diantaranya adalah kesiapan dalam belajar siswa, sehingga siswa benar-benar siap dalam mengikuti pelajaran, memperhatikan penjelasan materi, dan menjalankan proses diskusi, karena ada beberapa siswa yang kurang.

Hasil pengamatan aktivitas belajar siswa siklus 1 pada aspek psikomotorik didapatkan rata-rata dalam persentase sebesar $56,57 \%$ dengan kriteria aktivitas belajar siswa dalam kategori cukup, sehingga harus diingkatkan lagi untuk menjadikan pembelajaran yang ideal dan mendapatkan klasifikasi baik. Hal yang harus dibenahi diantaranya adalah keaktifan bertanya dan menjawab pertanyaanpertanyaan, sehingga siswa benarbenar berani dalam segi mental untuk menjawab pertanyaan dan mengajukan pertanyaan, selain itu kesesuaian produk yang dihasilkan di dalam melakukan kegiatan percobaan, serta mempresentasikan hasil pengamatan atau percobaan melalui lingkungan sekitar, karena ada beberapa siswa yang kurang.

2) Pengamatan keterampilan guru

Pengamatan keterampilan guru memperoleh persentase $76,87 \%$ atau kualifikasi baik. Walaupun sudah mencapai kualifikasi baik tetapi terdapat beberapa aspek yang perlu dibenahi untuk mencapai kualifikasi yang lebih baik lagi. Siklus 1 diketahui terdapat beberapa masalah yang perlu guru benahi yang menyangkut hasil belajar siswa, aktivitas belajar siswa, dan keterampilan guru. Oleh karena itu dalam pelaksanakan siklus II perlu diadakan perbaikan, yaitu:

a) Pada kegiatan pendahuluan, guru sebaiknya menjelaskan prosedur pembelajaran / dengan jelas agar siswa dapat mengerti apa saja yang akan dilakukan.

b) Guru perlu lebih jelas memberikan injelasan mengenai petunjuk kegiatan yang akan dilakukan oleh siswa dalam melakukan diskusi dan praktikum.

c) Guru lebih terampil dan bersemangat dalam memotivasi dan membimbing siswa sehingga siswa aktif dan antusias dalam diskusi kelas.

d) Guru sebaiknya membimbing siswa untuk menarik kesimpulan dan melakukan refleksi dari kegiatan yang telah dilakukan sehingga perlu adanya sesi tanya 
jawab dalam menarik

kesimpulan.

Pelaksanaan pembelajaran siklus II sudah berjalan dengan baik yaitu sudah memenuhi ketuntasan klasikal maupun individual hal ini didapatkan dari perbaikan atas refleksi pada siklus I, sehingga tidak perlu lagi melakukan siklus berikutnya. Adapun rician atau perbandingan siklus I dengan siklus II sebagai berikut: Berdasarkan penelitian yang telah dilakukan maka diperoleh hasil penelitian siklus I keterampilan guru mencapai persentase ketuntasan $76.87 \%$ "baik" dan mengalami peningkatan siklus II menjadi $84.37 \%$ dengan kriteria "baik". Hasil belajar IPA siswa ranah kognitif pada siklus I $52.63 \%$ dan pada siklus II meningkat menjadi $84.21 \%$. Hasil belajar IPA ranah afektif siswa siklus I mencapai persentase $56.67 \%$ dengan kriteria "cukup" dan siklus II meningkat menjadi $87.23 \%$ dengan kriteria "baik" dan ranah psikomotorik siswa siklus I mencapai persentase $56.57 \%$ dengan kriteria "cukup" dan siklus II meningkat menjadi $83.41 \%$ dengan kriteria "baik". Berdasarkan hasil penelitian tndakan kelas (PTK) yang telah dilakukan dapat disimpulkan bahwa penerapan model Contextual Teaching and Learning melalui pemanfaatan lingkungan selitar dapat meningkatkan hasil belajar IPA SD 1 Peganjaran Kudus.

\section{SIMPULAN DAN SARAN}

\section{Simpulan}

Berdasarkan hasil pembahasan penelitian tindakan kelas yang telah dilaksanakan, maka diperoleh simpulan bahwa melalui penerapan model CTL dapat meningkatkan hasil belajar IPA siswa materi sifatsifat cahaya di kelas V SD 1 Peganjaran. Hal ini dibuktikan bahwa telah terjadi peningkatan keterampilan guru dalam pengelolaan pembelajaran, hasil belajar aspek kognitif, afektif dan psikomotorik. Skor keterampilan guru dalam pengelolaan pembelajaran pada siklus I keterampilan guru mencapai persentase ketuntasan $76.87 \%$ "baik" dan mengalami peningkatan siklus II menjadi $84.37 \%$ dengan kriteria "baik". Hasil belajar IPA siswa ranah kognitif pada siklus I $52.63 \%$ dan pada siklus II meningkat menjadi 84.21\%. Hasil belajar IPA ranah afektif siswa siklus $I$ mencapai persentase $56.67 \%$ dengan kriteria "cukup" dan siklus II meningkat menjadi $87.23 \%$ dengan kriteria "baik" dan ranah psikomotorik siswa siklus I mencapai persentase $56.57 \%$ dengan kriteria "cukup" dan siklus II meningkat menjadi $83.41 \%$ dengan kriteria "baik".

\section{Saran}

a. Guru

Guru hendaknya menggunakan lingkungan sekitar sebagai alternatif pemilihan media yang tepat guna dalam setiap pembelajaran dan 
disesuaikan dengan materi pelajaran yang akan diajarkan.

b. Siswa

Pembelajaran dengan menggunakan model CTL diharapkan siswa lebih kompak dalam kelompok karena ada tujuh komponen yang harus dikakukan siswa agar pembelajaran lebih menarik dan terkasan.

c. Sekolah

Memberikan dorongan kepada guru agar dapat mengembangkan kemampuan sesuai tuntutan zaman.

d. Peneliti

Hendaknya peneliti selalu mengembangkan wawasan dalam perubahan dan peningkatan hasil belajar siswa terutama yang berkaitan dengan penerapan model CTL pada mata pelajaran IPA.

\section{DAFTAR PUSTAKA}

Aly, Abdullah dan Eny Rahma. 2000. Ilmu Alamiah Dasar. Jakarta: PT. Bumi Aksara

Andriyanto, Dedy. 2011. Memanfaatkan Lingkungan Sebagai Sumber Belajar Anak Usia Dini. Jakarta: Depdiknas

Daryanto dan Mulyo Raharjo. 2012.

Model Pembelajaran Inovatif. Yogyakarta: Penerbit Gava Media

Hanifah, Abu Nuha. 2012. Sains dan

Penemuan yang Mengubah

Dunia. Yogyakarta: Familia

Sanjaya, Wina. 2007. Strategi

Pembelajaran Berorientasi
Standar Proses Pendidikan.

Jakarta: Kencana Prenada Media Group

Suprijono, Agus. 2013. Cooperative Learning Teori \& Aplikasi Paikem. Yogyakarta: Pustaka Pelajar

Suwandi, Sarwiji. 2011. Penelitian

Tindakan Kelas (PTK) dan Penulisan Karya Ilmiyah. Surakarta: Yuma Pustaka 